\title{
A "Youth Multi-function Centre" in the Free State: An alternative to clinic-based HIV/AIDS prevention and care
}

\author{
C Heunis, M.Soc.Sc, Centre for Health Systems Research \& Development, UOFS \\ D van Rensburg, M.A., D.Phil, Centre for Health Systems Research \& Development, \\ UOFS
}

C Ngwena, LLB, LLM, Faculty of Law, Vista University (Bloemfontein Campus)

\begin{abstract}
The youth are especially vulnerable to the HIV/AIDS epidemic in South Africa. In the Free State (second highest incidence of HIV/AIDS among the provinces), the Welkom-Goldfields area may for various reasons be singled out as a high risk area for HIV/AIDS which should receive priority attention in attempts to combat the disease. It is suggested that a Youth Multi-function Centre would place youth reproductive health care in the broader development and life skills arena - where it could be thought to rightfully belong. The objectives of the paper are to depict the rationale for a Youth Multi-function Centre, to broadly conceptualise a Youth Multi-function Centre, and to report on the process and methodology followed in an attempt to actually establish such a centre in Thabong/Welkom.
\end{abstract}

\section{Abstrak}

In die loop van die MIV/VIGS epidemie in Suid Afrika is die jeug besonder kwesbaar. In die Vrystaat (tweede hoogste MIV/VIGS insidensie onder die provinsies) kan die Welkom Goudveld area vir "n verskeidenheid redes as "n hoë-risiko area uitgesonder word en behoort hierdie area in die stryd teen die epidemie prioriteit te geniet. Dit word aan die hand gedoen dat jeug reproduktiewe gesondheid deur ' $n$ Jeug Multi-funksie Sentrum in die breër arena van ontwikkeling en lewensvaardighede geplaas sal word - daar waar dit na regte behoort. Die oogmerke van die artikel is om die rasionaal vir ' $n$ Jeug Multi-funksie Sentrum te verduidelik en 'n breë konseptualisering van ' $n$ Jeug Multi-funksie Sentrum uit te voer, asook om verslag te doen van die proses en die metodologie om so ' $n$ sentrum in Thabong/Welkom te vestig.

\section{Introduction}

More than half of the world's population is under 25 years of age, and most of the world's youth - more than 80 percent live in developing countries. Around the world a significant number of adolescents are sexually active at an early age, with an increasing proportion of this activity occurring outside marriage. In South Africa, HIV/AIDS has affected young men and women more directly than any other age cohort (National Youth Commission 1997). Antenatal clinic attendance statistics for South Africa for the period 1995 to 1999 indicate the highest prevalence of HIV amongst women 20 to 24 years and 25 to 29 years of age $(1999=>25$ percent $)$ (Williams et al. 2000:307). For the period 1997 to 1998 the highest rate of increase has been observed in women younger than 20 years (65,4 percent) (Adler \& Qulo 1999:304).

In 1998 a group of researchers, primary health care (PHC) practitioners and non-governmental organisation (NGO) staff in the Free State formed a study group, the Youth Multi-function Centre (YMC) Taskgroup, based at the Centre for Health
Systems Research \& Development (University of the Free State), to examine youth reproductive health care and the role played by PHC clinics in combating HIV/AIDS among young people in the province. The YMC Taskgroup came to the realisation that public PHC services, for various reasons, are relatively ineffectual (in the sense of not reaching the youth) in rendering effective reproductive health services (education and care) to young people, and adolescents in particular.

The concept of a youth multi-function centre with an effective reproductive health service emanates in main from three observations: (i) the youth are particularly susceptible to HIV/ AIDS; (ii) socio-cultural and socio-economic factors predispose the majority of the youth in South Africa to HIV/AIDS; and (iii) public health policy in South Africa fails to effectively single out the youth as far as HIV/AIDS prevention and care are concerned. The YMC Taskgroup believes that a youth multi-funtion centre could go far in reaching the youth with appropriate reproductive information and care amidst 


\section{Figure 1 : Age prevalence of women attending antenatal clinics (1995-9)}

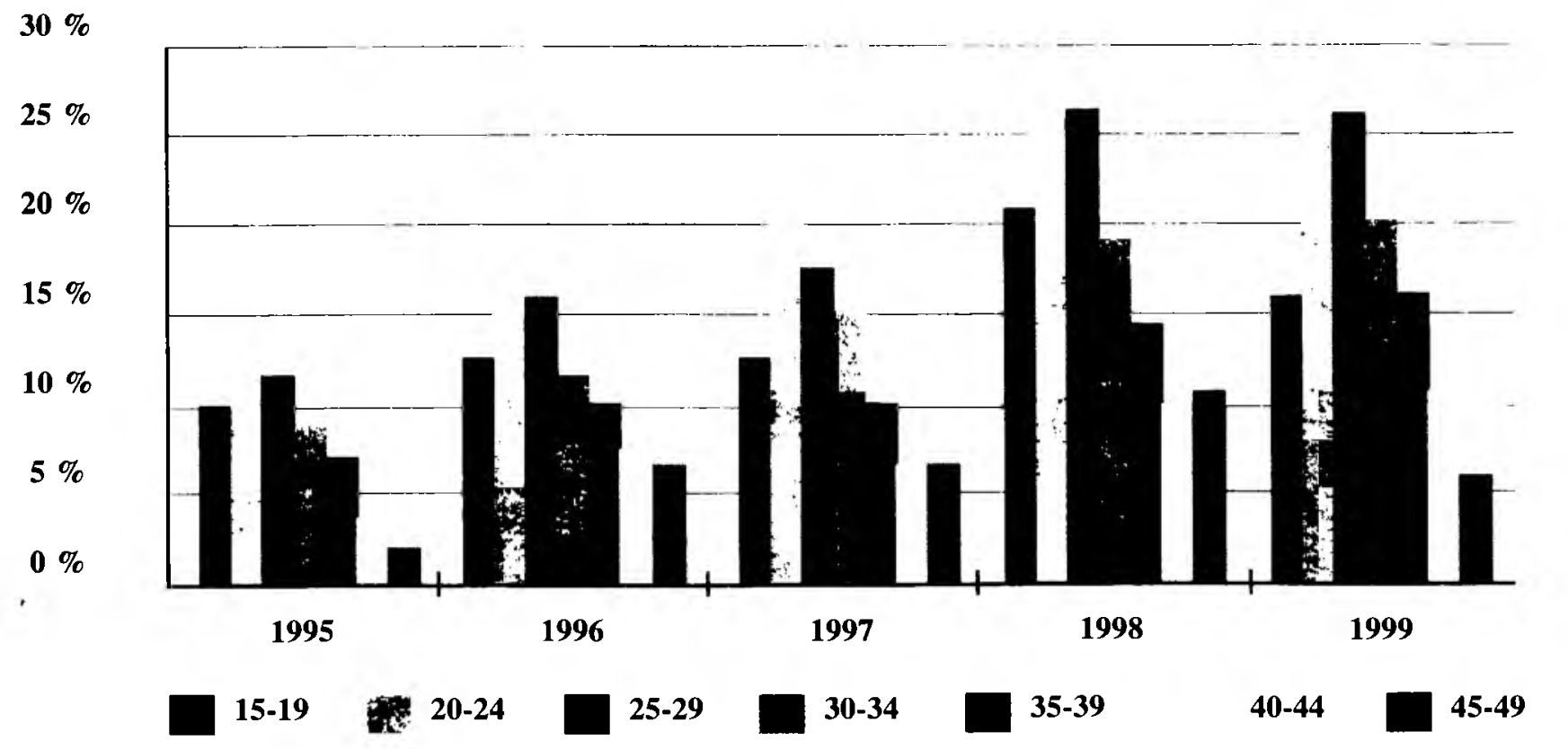

Source : Williams et al. 2000:307

other developmentally-relevant activities.

\section{Youth's special vulnerability to HIV/AIDS}

The Joint United Nations Programme on HIV/AIDS (UNAIDS) chose to carry out its 1998 World AIDS Campaign for, and with, young people - and did so for three reasons: "One is the special vulnerability of young people to the epidemic. Of all those infected after infancy, at least half are young people under 25. Another reason is that young people aged 10-24 account for more than 30\% of all people in the developing world where the epidemic is concentrated ... Most important, working with young people makes sense because they are a force for change. They are still at the stage of experimentation and can learn more easily than adults to make their behaviour safe or to adopt safe practices from the start" (UNAIDS 1998).

Young women have both a biological and a socio-economic vulnerability to HIV infection. According to Taylor (1999:54), the efficiency of transmission from men to women is thought to be seven times greater than from women to men in South Africa. Specifically, younger women are at even greater biological risk - their physiologically immature cervix and scant vaginal secretions put up less of a barrier to HIV. Tearing and bleeding during intercourse, whether from "rough" sex or rape, multiplies the risk of HIV infection. Also, sexually transmitted diseases (STDs) in women more often go unrecognised because sores or other signs are absent or hard to see. In fact, between half and four fifths of STD cases in women are unrecognised (Avert 1999:2).

Young women's greater socio-economic vulnerability to HIV/ AIDS stems from them often lacking economic resources of their own or being fearful of abandonment or violence on the part of their male partners. Also they have less control over how and when to have sex, and hence, over their risk of becoming infected with HIV. Male domination characterises value systems and behaviour patterns in much of South Africa. Girls are also socialised to leave initiative and decisionmaking in sex to men. Males are expected to dominate and there is often tolerance for male predatory and violent sexual behaviour. Male infidelity is allowed or even tacitly expected, while women are blamed or thrown out. In developing communities young women often heavily rely on "sugar daddies" and sporadic or permanent prostitution.

A breakdown in tradition and formal culture is taking place in South Africa. According to Craig \& Richter-Strydom (in Kunene 1995:49), because of a breakdown in traditional family lifestyles, African teenagers are nowadays very rarely educated in reproductive matters within their family contexts. Traditional mores and structures such as rituals of initiation into adulthood until recently existed as systems of education on sexuality in many cultures. Today, however, many of these practices have disappeared in the wake of modernity, leaving nothing in their place to educate adolescents about their sexuality.

Another major issue regarding adults in relation to youth reproductive health, is that parents often believe that sex education leads to earlier or increased sexual activity among adolescents. A World Health Organisation (WHO) review of programmes around the world, recently updated by UNAIDS (1998), revealed the contrary. The review showed that:

- Life skills needed for responsible and safe behaviour can be learned

- Good-quality educational programmes help delay first intercourse and protect sexually-active young people 
Sex education encourages safer sexual behaviour

Even where there had been little impact on condom use, programmes have led to a delay in the age of first sex

The reproductive health needs and problems of young people in Southern Africa are embedded in the socio-cultural, economic and political settings in which they grow up. Recognition of young people as a unique group can help minimise the problems and meet their total needs. Problems relating to reproductive health impact negatively on young people's development and welfare. These problems pose a daunting challenge to such service providers as nurses, community leaders, teachers, parents and young people themselves.

\section{Reproductive health policy failing to single out the youth}

There are many ways of defining reproductive health. Different definitions and priorities are being proposed by HIV/AIDS activists, women's health advocates and family planning organisations. Generally, good reproductive health should include freedom from risk of sexual diseases, the right to regulate one's own fertility with full knowledge of contraceptive choices, and the ability to control sexuality without being discriminated against because of age, marital status, income, or similar considerations (International Conference on Population and Development 1994). Achieving such goals will require any facility to wisely use scarce resources, which may include ways to integrate different reproductive services. For example, STD/HIV/AIDS, family planning programmes and other reproductive health projects may share certain services, such as maintaining a central file of patient records. Important is that the client needs and culture of each community be considered. "To look at reproductive health means looking at all aspects of people's lives" (Hardee in Keller 1995:22). The Beyond Awareness Campaign has indicated that it is possible to apply an integrated HIV/AIDS strategy at national, provincial, regional or local level: "Every situation requires active research, clear goals and objectives and includes consideration of resources that will support activities. Each level of strategy and intervention requires a related strategy for communication and evaluation" (Parker et al. 1998: 15).

While the high-tech orientated health system of the past is supposedly shifting towards a person orientated PHC care system, progress in fully integrating the vertical and fragmented family planning services of the past into PHC, is slow. Progress is being hampered by the arduous task of developing a solid district health system with community participation as prerequisite. Inequity in access to effective MCWH (Mother, child and women health) exists particularly in previously disadvantaged rural areas, as well as in many highdensity urban and peri-urban areas and informal settlements (United Nations Population Fund 1998:49). According to CASE (in HST Update 1999:5) almost all young white (95 percent) and Indian ( 93 percent) persons are able to access health care within 30 minutes, whilst only 61 percent and 84 percent of respectively African and coloured young people can do so.

Although it appears as though the necessary structures for STD treatment and comprehensive reproductive health care have already been implemented in South Africa, the practical limitations hampering their proper functioning, are still numerous (National STD/HIV/AIDS Review 1997:7). One of these hampering factors is the lack of properly trained counsellors. Kunene (1995:49) established that health workers are to act as counsellors to adolescents, but that no proper monitoring mechanism exists for the supervision of counsellors to ensure that adequate services are rendered. Some counsellors receive very limited training with no follow-up supervision whatsoever.

Obstructive, judgmental and moralising attitudes amongst health workers also influence the health-seeking behaviour of teenagers (Fuglesang 1997:1245-54). Some health workers refuse adolescents contraceptives fearing that this could encourage pre-marital sexual relationships (Kunene 1995:49). In a study amongst teenagers in Northern Province, teenagers voiced discontent with health workers' judgmental attitudes regarding adolescent sexuality (Wood et al. 1997). This study noted that one of the most problematic aspects of clinic attendance for teenagers was that nurses would not provide condoms before asking questions about their sexual relations and lecturing them on being too young to have sex.

The South African Demographic and Health Survey of 1998 has shown that South African women experience first sexual intercourse at a median age of eighteen years, while at an even younger age for rural women. By the age of nineteen years 35 percent of all teenagers have been pregnant or have had a child (South African Demographic and Health Survey 1999:27).

Studies have also shown that the health seeking behaviour of adolescents in relation to STDs differ substantially from that of adults (Fortenberry 1997; WHO Press Release. 1998:1). Teenagers, and especially teenage women, tend to delay health seeking for STDs longer than adults. In fact, the tendency to delay seeking of health care partially explains the high rates of STDs among adolescents. However, it is acknowledged that the so-called "procrastination" interval may often be ascribed to factors that are not always in young people's control, particularly lack of access to ("youth-appropriate") health services.

It is therefore proposed that the reproductive health needs of adults and youths cannot be optimally fulfilled underneath the same roof. At least in high incidence, urban settings unique reproductive health facilities catering exclusively and appropriately for the youth are a necessity.

\section{Motivating for a Youth Multi- function Centre in Thabong/ Welkom}

\section{Why a Youth Multi-function Centre?}

Makhanya (1999) argues for a multi-sectoral approach: “... [T]he HIV/AIDS pandemic has helped us to realise the effects of using a disease profile in crafting health care responses. Within the South African context, the 'single disease approach' will not be particularly helpful in addressing 
the health needs of the youth. Instead a broad based strategy reflecting a partnership between all relevant sectors would be a logical approach in addressing youth health, irrespective of prevailing diseases." Avert (1999a:2) expounds the idea of a youth multi-function service: "The kind of services that are found most acceptable and appropriate by young people are those that offer a range of integrated services, are accessible at evenings and weekends, are close to public transport, have an appropriate image and atmosphere, and have approachable, non-judgmental and reassuring staff." PPASA (Planned Parenthood Association of South Africa), who currently follows a health model in the provision of youth services, also expounds the idea of a more comprehensive model for the future: "There is only so much a health model can do, and we need to move further particularly if we are to reach the ones who are most vulnerable - those who are out of school ... By getting youth who are not in school to come along to the centre for recreational activities or to learn a new skill, they can then be pulled in for health services and education on reproductive health"(Strachan 1999:8).

According to McNair \& Brown (1996:347), an adolescent health service, under youth friendly circumstances, could go a long way in providing an effective, as well as exciting, new alternative to conventional health services. For many teenagers requiring confidential management of sexual health matters, the conventional system of health care provision and counselling is inappropriate. With obstacles such as time constraints, high patient loads and the complexity of patient problems already blocking the way towards ideal levels of service provision, health care personnel are obviously not favourably equipped to deal with the very sensitive needs and questions teenagers might come up with. Kunene (1995:50) found that only 26 percent female and 23 percent male youths in the Western Province made use of an integrated (adult) health centre, showing the degree of under-utilisation and/or avoidance of such services.

\section{Why the Free State and Thabong/Welkom?}

The population of the Free State province numbers 2,6 million (Development Bank Southern Africa 2000:63), with Region $\mathrm{C}$ (Tshepano or Welkom region) housing more than a quarter (27 percent - some 750000 people) of the provincial population (Centre for Health Systems Research \& Development 1996:15). Thabong/Welkom is situated in the Free State Goldfields area, the mining and industrial hub of the province, and also the focal point of migrant mine workers from other provinces and Lesotho and other Southern African countries.

According to the National Syphilis Survey of Women Attending Antenatal Clinics of the Public Health Sector in 1998, the Free State had the highest syphilis prevalence among pregnant women of all nine the provinces $(18,4$ percent compared to a national average of 11 percent). The corresponding figure for Region C in the Free State was 18,2 percent (Department of Health: 1998: 17-19). Recently Mullick et al. (1999) conducted an assessment of quality of care for STDs in the Kopano district which showed that STD control in the Welkom/Thabong area is lacking in a great many respects.

After KwaZulu-Natal (32,5 percent), the Free State (27,9 per- cent) currently has the highest HIV prevalence for women attending antenatal clinics of the nine provinces in South Africa (Department of Health 2000: 14). Within the Free State, Region C in 1997 had the highest HIV prevalence amongst antenatal clinic attendants of the six health regions in the province (Region $\mathrm{C}-26,6$ percent; Region $\mathrm{E}-25,8$ percent; Region D - 17,7 percent; Region A - 17,6 percent; Region F - 17,5 percent) (Department of Health 1998: 12-14). Only three regions in KwaZulu-Natal (Empangeni, Ulundi/Vryheid and Durban) had higher prevalence rates than the Tshepano Region. Of all the health regions in South Africa, Tshepano had the fifth highest HIV infection rate amongst pregnant women making use of public health care. These statistics are all the more worrying considering that antenatal surveys might underestimate the overall HIV prevalence rate in a target population as confirmed in recent studies in Uganda (Gray et al. 1998: 98-103).

\section{Methodology}

The project, which is ongoing, has thus far comprised four major activities: (i) literature study, (ii) study visits to existing youth centres, (iii) consultation with stakeholders in Thabong/Welkom, and (iv) establishment of structures to ensure the continuance of the initiative. The literature study, study visits to existing youth centres, and a first conceptualisation of the envisaged Centre have been published by the Centre for Health Systems Research \& Development in a research report: Combating HIV/AIDS amongst youth in South Africa: A Youth Multi-function Centre for Thabong Welkom in the Free State province, which is being used in a concerted effort to raise funds for the establishment of the Centre. This document has also been used as a basic working document during a protracted series of consultation sessions with the youth, civil society, and local government organs in the target community, as well as the provincial government ${ }^{1}$.

1

The stakeholder groups consulted can be grouped into six categories Youth organisations/structures:

- African National Congress (ANC) Youth League

- Azanian Youth organisation

- Friends for Life

- National Community Theatre for Education and Development Network

- Thabong Art and Culture Association

- Thabong Youth Development Organisation (TYDO)

- Ufundo-ujema Fundraising Organisation

- Welkom Junior City Council

Welkom Anti-AIDS Youth Club

Development organisations/structures:

- Free State-Goldfields Development Centre

- Lesedi/Kopano Project

- Hospice

- Learn Association

- Welkom Development Forum

Local authority departments/divisions:

- Local Youth Unit

- Parks, Sport and Recreation

- Welfare

> Welkom City Council (Standing Committee)

Provincial government departments/divisions:

- Department of Health (Region C)

$>\quad$ HIV/AIDS/STD Programme

Mine groups:

- Anglogold

- Harmony

Business:

- Thabong Business Association

- Harmony Mine 
Structures for the furtherance of the project that have been established and have been engaged in the refinement of the proposed model and the drawing up of a funding proposal for the establishment and first three years of operation of the Centre. These structures include a widely representative Steering Group, a Board of Trustees and its Executive Committee.

\section{Conceptualising the Youth Multi-function Centre}

The research, study visits and consultation process have lead to the following conceptualisation of the Thabong/Welkom Youth Multi-function Centre:

\section{"Identity" of the Youth Multi-function Centre}

All interest groups consulted felt that the Centre should be non-partisan in terms of its political, ethnic, religious and gender characteristics. This was seen to be crucial if the Centre were to be perceived as a place where youth (from any background) are welcome. The Centre should also not have a "government" or "local authority" identity or be seen as an institution driven by any particular organisation.

A very important consideration is that the Centre should also not be one-sidedly or negatively labeled as a "clinic" or a "health centre". This aspect was emphasised over and again by consulted organisations. It was felt that should the Centre be characterised by concepts such as health, HIV/AIDS or sexuality education, its intended purpose would never be achieved. The "multi-function" image of the Centre should characterise its nature, image and marketing. Thus, the original motivation for the Centre, namely to curb the rapid spread of STDs and HIV amongst the youth, is never to be emphasised in the way the Centre is established and marketed to the youth. Even within the Centre, the "health room", should be "tucked away" to the extent that other activities are seen to be more characteristic of the Centre's nature and purpose.

The Centre should be seen as an independent and locally "owned" establishment encompassing the participation of a variety of role players in its establishment, functioning and management, and foremost amongst these the youth and organised youth formations. Active youth involvement in the establishment and management of the Centre (not as a form of tokenism to legitimise it) is an important prerequisite and real and sustained involvement should be fostered. This implies that mechanisms should be put in place for the youth to identify their own needs and preferred strategies for meeting them. Youth programmes should also endeavour to draw out and nurture youth leadership.

\section{Range of activities at the Youth Multi- function Centre}

An important consideration was that the Centre should fill a unique niche in the range of services already available in the community. In Thabong/Welkom the following functions/activities were identified as necessary for youth development and attendance of the Centre:

$>$ Access to computers and basic computer literacy training, as well the "Internet"

$>\quad$ An information and referral service on training and employment opportunities for youths

$\rightarrow \quad$ A small conference facility

- Entertainment such as drama, debates, dancing, music, shows and beauty contests

b A small "youth-appropriate" library

$\downarrow \quad$ Offices for youth organisations

$>\quad$ A youth rape crisis service

- An out-of-school youth literacy programme

$\rightarrow$ Skill development programmes with an actual production thrust

- A leisure room with recreational facilities

$>\quad$ A health (or reproductive health and sexuality education) service or "room"

$>\quad$ Facilities and opportunities to develop entrepreneurial skills and engage in small business activities

\section{The "health room" within the Youth Multi- function Centre}

Poor accessibility to reproductive health services is one of the most serious barriers preventing youths from making use of the health care services available to them. Since it is clear that there are a very complex assortment of factors that prevent youths from seeking reproductive health care, a multifaceted approach should be followed. In this regard the Youth Multi-function Centre provides a number of possibilities that might be able to deal with all, or at least with most, of these shortcomings. Some of these possibilities are to:

$>\quad$ Extend opening hours to include evenings and weekends

2. Discourage/prohibit adults from making use of the services provided by the Centre

- Employ health care providers who are youthful and/or have a record of achieving success with the youth

$>$ Ensure the possibility of personal attention (one-onone consultation) to youths visiting the Centre

$>\quad$ Provide specialised training to staff members in how to handle the unique reproductive problems of youths Promote the fact that the Centre has a preventative as well as a curative function and that youths are free to make use of both

The literature also suggests that successful youth health services have to be both preventative and curative. When dealing with sexual matters and prevention strategies, emphasis should fall on harm reduction rather than on a punitive approach. However, if the harm has already been done, health care providers should be qualified and able to assist in the curing of ailments. Health care facilities should therefore be able to present a dual service of prevention and medication/methods to youths at any time.

Given that HIV/AIDS in South Africa is closely linked to the high prevalence of tuberculosis and STDs, these diseases have to form part of the scope of preventative and curative treatments at a youth reproductive health service. It is especially important to treat tuberculosis and STDs early in order to reduce the duration of the infectious period.

The health room within the Centre would aim to:

$>\quad$ Create an awareness and improve young people's knowledge regarding sexual health, contraception and preventive measures 
- Drastically raise the inquiry and help seeking rates of youths

Initiate STD screening

- Ensure the continuity and regularity of visits

- Reduce risk-taking behavior

With regard to the health room's preventative function, family planning/STD/HIV/AIDS information, education and communication (IEC) campaigns and programmes should take place at and from the Centre. The health room will provide a continuous consultation service to youths. The underlying philosophy of the IEC service will be that every person is entitled to information about the range of contraceptive choices available and should have the ability and skills to control sexuality without fear of being discriminated against because of age, gender, marital status, etc. The health room should provide around-the-clock access to barrier methods (free of charge). The following care functions may also form part of its ambit of services: STD/HIV/AIDS control and treatment, tuberculosis control and treatment, tuberculosis, STD and HIV-testing, and contact tracing.

Nowadays "Enter-Educate" (Entertainment-educate) is an important and popular way to reach young people with messages about sexual relationships, protection from pregnancy and disease, and education and empowerment of women. The following media may be employed by the Youth Multi-function Centre, and the "health room" in particular:

- Interactive media: Internet-linked computers in the

Centre should be available for youths to access what ever information they need, and to be used to tap into the latest information on HIV/AIDS and ways to combat it amongst the youth

- Audio-visual media: television, videos

- Songs, drama, role play, debates, competitions and talks

- Print media: leaflets, booklets, flipcharts, posters, stickers

- Utility items: T-shirts, caps, peaks, badges, pens, rulers, key rings

Peers are considered to be the single most influential source of sex information among adolescents. Therefore the health room may host:

- Student-lead programmes

> Training of trainers and peer out-reach activities in Thabong/Welkom

- $\quad$ "Bring-a-friend" activities at the Centre

\section{Skills development and "training through production"}

Efficient youth reproductive health programmes combine health education with development programmes, and thereby seek to address the underlying causes of high risk behaviour and early fertility, such as poverty and the low social status of young women. Ideally, training in marketable skills for youth should form part of the concept. However the training should not be focused on to the extent that the Youth Multi-function Centre becomes a training centre. General life-skills development, recreation and reproductive health services should be seen as equally important. As far as possible "training should pay its own way", i.e. by following the example of an organisation like the Joint Enrichment Project in Johannes- burg who secures contracts from Local Authorities for projects such as the refurbishing of community halls.

Training could take the form of short-term certificate courses with a substantial practical component. Trainees should also be exposed to other services in the Youth Multi-function Centre, including general lifeskills development and reproductive health counselling and services. If possible trainees will earn limited stipends during training, but a fixed percentage of the profits should go back to the Centre. "Non-profitable" training should also take place where funding and other resources can be secured. The process of fairly and objectively selecting trainees should be stipulated in the Centre's constitution.

\section{The targeted age group of the Youth Multi- function Centre}

The definition of "youth" varies according to the source. "Clearly there is a need for harmonisation across policies on these matters" (HST Update 1999: 5). According to Thornburg (in Jacobson et al. 1994: 11), half of sexual information is learned by the ages of 12 and 13 , which suggests that young teenagers cannot be excluded if effective reproductive health care is to take place. Topics pertaining to intimacy, gender role expectations, communication, anatomy, physiology and contraception need to be addressed prior to adolescence, so that those who are running a high risk of unintentional pregnancy and STDs, can prevent it from actually happening to them.

While most writers feel that children should receive reproductive health care from the ages of 12 and 13, Frame et al. (1991:6) argue that sexual behavior should be shaped long before it actually starts to set in. Intervention must commence prior to the age of thirteen. Similarly, Martin (1993: 24) argues that reproductive health care should begin as early as 10 years old, since the physical, social and emotional characteristics of youths, that make them unique, already starts to emerge at this age. All indications, therefore, point to the fact that children should start to receive reproductive health care by the age of 12 , while life skills education, primarily focused on the development of positive self esteem, could commence even earlier.

Universally, however, the highest STD and HIV infection rates are in the age group 20 to 24 years of age, followed by 15 to 19 years - which implies that these groups are to receive special attention in the Youth Multi-function Centre, at least as far as the reproductive health function is concerned.

The general opinion among the organisations/structures consulted was that the Centre should broadly target people 14 to 35 years of age. The vast age difference between someone who is 14 and someone who is 35 years old, however, points to the need for programmes within the Centre to target specific age categories for specific purposes. As far as reproductive health is concerned, it may be appropriate to have specific programmes for pre-teens (younger than ten years) and early teens (10 to 15 years). Within the main target group, (16-35 years) programmes may be directed towards schoolgoing and out-of-school youth, while it should be noted that in our country the school-going youth often include people 
Table 1 Comparing the advantages of a Youth Multi-function Centre over current services

\begin{tabular}{|l|l|l|}
\hline \multicolumn{1}{|c|}{ CURRENT SERVICES } & \multicolumn{1}{|c|}{$\begin{array}{c}\text { YOUTH MULTI-FUNCTION } \\
\text { CENTRE }\end{array}$} & $\begin{array}{c}\text { ADVANTAGE OF THE YOUTH MULTI- } \\
\text { FUNCTION CENTRE }\end{array}$ \\
\hline Health care to adults and youths & Health care exclusively to youths & Youths do not feel threatened or self-conscious \\
\hline Provides health care only & $\begin{array}{l}\text { Combines health services with other } \\
\text { recreational and educational activi- } \\
\text { ties }\end{array}$ & $\begin{array}{l}\text { Provide youths with an opportunity to socialise } \\
\text { with their peers and to receive essential health } \\
\text { care without the embarrassment that comes with } \\
\text { actually visiting a clinic }\end{array}$ \\
\hline $\begin{array}{l}\text { Service providers are not always } \\
\text { properly trained in dealing with } \\
\text { the health problems of youths }\end{array}$ & $\begin{array}{l}\text { Service providers will specialise in } \\
\text { dealing with the reproductive health } \\
\text { care needs of youths }\end{array}$ & $\begin{array}{l}\text { Staff members are thoroughly equipped to deal } \\
\text { with the unique reproductive health care needs of } \\
\text { the youth }\end{array}$ \\
\hline $\begin{array}{l}\text { Financially dependent on govern- } \\
\text { ment }\end{array}$ & $\begin{array}{l}\text { Only partially dependent on govern- } \\
\text { ment }\end{array}$ & $\begin{array}{l}\text { Funded by donors, mine groups and local busi- } \\
\text { ness. Will to some extent become self-sustaining } \\
\text { by hosting "training through production" and } \\
\text { entrepreneurial activities. }\end{array}$ \\
\hline Government-image & $\begin{array}{l}\text { The Centre should have a trendy and colourful } \\
\text { appearance and image. }\end{array}$ \\
\hline $\begin{array}{l}\text { A mere service institution cater- } \\
\text { ing mainly for adults }\end{array}$ & A place of opportunity for youths & $\begin{array}{l}\text { Youths can make contacts, get information, en- } \\
\text { gage in certificate skills-development pro- } \\
\text { grammes. }\end{array}$ \\
\hline $\begin{array}{l}\text { Under aged children's parents } \\
\text { have access to their clinic records }\end{array}$ & $\begin{array}{l}\text { Confidentiality in reproductive mat- } \\
\text { ters will be ensured, even from par- } \\
\text { ents }\end{array}$ & $\begin{array}{l}\text { Adolescents will feel more secure in obtaining } \\
\text { information and methods. }\end{array}$ \\
\hline
\end{tabular}

Source: Williams et al. 2000:307.

20 years and older. Programmes can therefore also be classified as for:

- Pre-teens (younger than 10 years)

- Young teenagers (10-14 years)

- Teenagers/young people ( 15 to 19 or 15 to 24 years)

- Young people/young adults (25-35 years)

\section{Please send your comments and suggestions to Christo Heunis - e-mail heunisj@opv.uovs.ac.za /fax 051-4480 370 / tel 0514480370.}

\section{Comparison in summary}

The growing health needs of young people are to be prioritised and addressed as a matter of urgency, as it seems that insufficient, or perhaps more accurately, misdirected attention is paid to primary prevention intervention strategies for youths (Atwood \& Donnelly 1993: 219). It has become very clear that something new, that would enable youths to make responsible decisions regarding their sexual behaviour, has to be conceived. This will have to be a facility that can ensure unprejudiced, professional and efficient care, in order that the youths who attend it could feel confident, comfortable and safe. Table 1 reflects a comparison of the Youth Multifunction Centre to the existing situation pertaining to (public) youth reproductive health care: The Thabong/Welkom Youth Multi-function Centre is a dream shared by many people and a variety of interest groups and organisations. Should such a Centre realise, it could serve as a pilot and a model for other communities in the Free State, and further afield.

\section{Acknowledgement}

The Centre for Health Systems Research \& Developinent gratefully acknowledge the generous support of the Skalth Systems Trust and the GTZ towards the research component of the project. 
ADLER G \& QULO O 1999: HIV/AIDS and STDs. In Crisp N \& Ntuli A (Eds.) 1999. South African Health Review. Durban: Health Systems Trust. pp.301-313.

ATWOOD JD \& DONNELLY JW 1993: Adolescent pregnancy: combating the problem from a multi-systemic health perspective. Journal of Health Education. 24(4): 219-227.

AVERT 1999: Women, HIV and AIDS. http://w'w'avert.org/ womenaid.html.

AVERT 1999A: AIDS education and young people. http:// www.avert.org.schsexed.html.

\section{CENTRE FOR HEALTH SYSTEMS RESEARCH \&} DEVELOPMENT 1996: Health care in the Free State: Implications for planning. Durban: Health Systems Trust; Pretoria: Department of Health.

DEPARTMENT OF HEALTH 1998: Eigth annual national HIV sero-prevalence survey of women attending antenatal clinics in South Africa. Pretoria: Health Systems Research \& Epidemiology.

DEPARTMENT OF HEALTH 1999: Syphilis sero-prevalence among women attending antenatal clinics in South Africa, 1998. Statistical Notes, 2(6):2-3.

DEPARTMENT OF HEALTH 2000: Summary report: National HIV sero-prevalence survey of women attending public antenatal clinics in South Africa 1999. Pretoria: Directorate: Health Systems Research, Research Co-ordination \& Epidemiology

DEVELOPMENT BANK SOUTHERN AFRICA 2000: South Africa: Inter-provincial comparative report. Halfway House: Development Information Business Unit.

FORTENBERRY JD 1997: Health care seeking behaviours related to sexually transmitted diseases among adolescents. American Journal of Public Health, 87(3):417-420.

FRAME G; FERRINHO P \& EVIAN C 1991: Knowledge and attitudes relating to condoms on the part of African high school children around Johannesburg. Curationis, 14(2):6-8.

FUGLESANG, M 1997: Lessons for life - past and present modes of sexuality education in Tanzanian society. Social Science \& Medicine, 44(8):1245-1254.

GRAY RH; WAWER MJ \& SERWADDA D 1998: Population-based study of fertility in women with HIV - I infection in Uganda. The Lancet, 1998 (351): 98-103.

HEUNIS JC; VAN RENSBURG D (and others from the Free State Department of Health, Centre for Health Systems Research \& Development, Hippy, NACOSA, Thaba Nchu Youth Club, MRC, Department of Sociology (UFS), VISTA University and PPASA) 1999: Combating HIV/AIDS amongst youth in South Africa: A Youth Multi-function Centre for Thabong/Welkom in the Free State province Bloemfontein: Centre for Health Systems Research \& Development.

HST UPDATE 1999: Some points to ponder. HST Update, 44. July.

INTERNATIONAL CONFERENCE ON POPULATION AND DEVELOPMENT 1994: Programme of Action of the International Conference on Population and Development. New York: United Nations.

JACOBSON BH; ALDANA SG \& BEATY T 1994: Adolescent sexual behavior and associated variables. Journal of Health Education, 25(1): 10-12.

KELLER S 1995: Good reproductive health involves many services. Network, September 1995:19-22.

KUNENE PJ 1995: Teenagers' knowledge of human sexuality and their views on teenage pregnancy. Curationis, $18(3): 48-52$

MAKHANYA N 1999: Out of school youth join a force of social change: Sharing tactics for fighting HIV/AIDS. KwaZulu-Natal Department of Health in partnership with South African Broweries, AIDS Foundation of South Africa and the KwaZulu-Natal Youth Council.

MARTIN T 1993: “Turning points" revisited: how effective middle-grades schools address developmental needs of young adolescent students. Journal of Health Education, November/December 1993-supplement:24-27.

MCNAIR R \& BROWN R 1996: Innovative perspectives in youth health care. Australian Family Physician, 25(3):347351 .

MULLICK S; VARGA C \& STEEN R 1999: Assessment of quality of care for STIs in resource limited settings: Experiences with two methodologies in Kopano District, Free State Unpublished: Initiative for Sub-District Support. Health Systems Trust.

NATIONAL STD/HIV/AIDS REVIEW 1997: Department of Health.

NATIONAL YOUTH COMMISSION 1997: National Youth Policy. Pretoria: National Youth Commission.

PARKER W; DALRYMPLE L \& DURDEN E 1998: Communication beyond AIDS awareness: A manual for South Africa. Auckland Park: Department of Health/Beyond Awareness Consortium.

SOUTH AFRICAN DEMOGRAPHIC AND HEALTH SURVEY, 1998 1999: Preliminary Report. Department of Health

STRACHAN K 1999: A new way of reaching teenagers. 
HST Update, 44. July.

TAYLOR V et al. 1999: HIV/AIDS \& Human Development in South Africa 1998. United Nations Development Programme.

UNAIDS 1998: World AIDS Campaign with young people. http://1www:unaids.org/highband/events/wad/l 998/force.html.

UNITED NATIONS POPULATION FUND 1998: Republic of South Africa: Programme review and strategy development report. United Nations Population Fund.

WHO PRESS RELEASE 1998: World AIDS Day 1998 AIDS epidemic: Director-General urges health services to be more responsive to youth. http://hww.\$w pm6784. htm.

WILLIAMS BG; GOUWS E; COLVIN M; SITAS F; RAMJEE G \& ABDOOL KARIM SS 2000: Patterns of infection: Using age prevalence data to understand the epidemic of HIV in South Africa. South African Journal of Science, 96 (June): 305-312.

WOOD K; MAEPA J \& JEWKES R 1997: Adolescent sex and contraceptive experiences: Perspectives of teenagers and clinic nurses in the Northern Province. Pretoria: Medical Research Council. 